\title{
Prejudice against veiled Muslim women: The role of right-wing authoritarianism and intergroup anxiety
}

\author{
Annisa Puspita Inderasari, ${ }^{1}$ Marselius Sampe Tondok, ${ }^{1 *}$ Ananta Yudiarso ${ }^{1}$ \\ ${ }^{1}$ Faculty of Psychology, Universitas Surabaya, Surabaya - Indonesia
}

\begin{abstract}
A series of acts of terrorism involving women in various parts of the world, including in Indonesia, allegedly carried out by radical Muslim groups, has strengthened stereotypes and created prejudice against Muslim women who wear the veil. This study aims to explain the role of right-wing authoritarianism (RWA) and intergroup anxiety as antecedents of prejudice against veiled Muslim women. Using a cross-sectional survey design, the study sample $(\mathrm{N}=403)$, domiciled in the city of Surabaya, Indonesia, was selected by accidental sampling. RWA, intergroup anxiety, and prejudice against veiled Muslim women were measured using a questionnaire, and the research hypotheses was analyzed by multiple linear regression. The results show that RWA and intergroup anxiety play a significant role in explaining prejudice against veiled Muslim women $\left(\mathrm{R}=.826 ; \mathrm{R}^{2}=.682 ; \mathrm{F}=428.68 ; \mathrm{p}<.01\right)$, with the relative contributions of RWA and intergroup anxiety being 34\% and 66\% respectively. The theoretical implication of the research is that RWA and intergroup anxiety act as antecedents of prejudice against veiled Muslim women.
\end{abstract}

Keywords: intergroup anxiety; prejudice; RWA; veiled Muslim women

\begin{abstract}
Abstrak: Serangkaian aksi terorisme yang melibatkan perempuan di berbagai belahan dunia termasuk di Indonesia, yang diduga dilakukan kelompok Muslim radikal, telah menguatkan stereotip dan memunculkan prasangka terhadap perempuan Muslim bercadar. Penelitian ini bertujuan untuk menjelaskan peran right-wing authoritarianism (RWA) dan intergroup anxiety sebagai anteseden prasangka terhadap perempuan muslim bercadar. Dengan desain cross-sectional survey, sampel penelitian ini $(\mathrm{N}=403)$ berdomisili di Kota Surabaya yang dipilih dengan accidental sampling. RWA, intergroup anxiety, dan prasangka terhadap perempuan Muslim bercadar diukur menggunakan kuesioner dan hipotesis penelitian dianalisis dengan regresi linear berganda. Hasil penelitian menunjukkan RWA dan intergroup anxiety berperan secara signifikan dalam menjelaskan prasangka terhadap perempuan muslim bercadar $\left(R=0,826\right.$; $R^{2}=0,682 ; F=428,68$; $\mathrm{p}<0,01$ ), di mana sumbangan relatif RWA dan intergroup anxiety adalah $34 \%$ dan $66 \%$. Implikasi teoretis penelitian ini adalah RWA dan intergroup anxiety berperan sebagai anteseden prasangka terhadap perempuan muslim bercadar bercadar.
\end{abstract}

Kata Kunci: intergroup anxiety; prasangka; RWA; perempuan Muslim bercadar 


\section{Introduction}

Acts of terrorism, which are widespread phenomena, have occurred in various parts of the world, including the attack on the World Trade Center (WTC) and the Pentagon Headquarters in the United States on 11 September 2011 (Berty, 2018); the Paris attack in November 2015 (Utomo, 2018); Surabaya City in Indonesia in May 2018 (BBC News, 2018a). In 2019, there were various other acts of terrorism based on religion in Indonesia, where the perpetrators were not only men but also women (Halim, 2019).

Even though the majority of the Indonesian population is Muslim, at $87.18 \%$ (BPS, 2013), the veiling of women has not been widely accepted. Terror incidents in several countries have resulted in veiled Muslim women, both in western countries and in Indonesia, being perceived as symbols of controversy, division, security threats, fundamentalism, and acts of terrorism (e.g., Garcia Yeste et al., 2020; Karunia \& Syafiq, 2019; Rahman \& Syafiq, 2017; Rasyid \& Bukido, 2018; Soltani, 2016). However, such women are currently a minority group among the Muslim majority in Indonesia.

The stigma that grows in society regarding the free veil, with prejudice and nationalism shown against Muslim women who wear one. Some of the unpleasant treatment that veiled Muslim women have to endure includes being called thieves, having bottles thrown at them, and not being allowed get on buses because of their veil (BBC News, 2018b).

Prejudice is a negative attitude aimed at individuals who are part of certain social groups (Brown, 2010; Kite \& Whitley, 2016; McFarland, 2010; Myers \& Twenge, 2016; Nelson, 2016). Three aspects constitute prejudice (Cohrs et al.,
2012), namely: 1) cognitive aspects of individual beliefs in social groups; 2) affective aspects related to individual emotional reactions to negative and positive influences, as well as certain emotions on social groups; and 3) the conative aspect, which is an individual's tendency to behave based on avoidance or approach as a form of individual response to social groups.

In terms of theory, there are several factors that influence prejudice (Abrams, 2010), namely values, social categorization, clarity, personality, and individual personality. Emotional reactions that arise and are generally not realized by individuals are another factor that can explain prejudice (Kite \& Whitley, 2016; Nelson, 2016).

According to Allport (1954), personality is one of the factors which complements prejudice, one of which is right-wing authoritarianism (RWA) (McFarland, 2010). This is supported by research which states that RWA is a predictor of prejudice against social groups (e.g., (Choma et al, 2018; Crawford et al., 2016; Onraet et al., 2017). Myers and Twenge (2016) explain that authoritarian personality is the tendency of individuals to be obedient to authority and intolerant of other groups that have lower status. RWA explains the tendency of individuals to obey higher authorities, to be aggressive against outgroups, and to support pre-existing conventional regulations (Saunders \& Ngo, 2017). When a group violates conventional regulated rules (for example, being gay), individuals with high RWA tend to be more aggressive against that group (Crawford et al, 2016).

Altemeyer (1996) develops the RWA concept by describing three groups of attitudes which are aspects of it. First, authoritarian submission, the tendency of individuals to obey an established or 
powerful authority in society. Second, authoritarian aggression, the tendency to be aggressive against groups that violate conventional rules. And third, conventionalism is the tendency of individuals to support conventional rules or values that apply in society, especially when these regulations are fully supported by the authorities. These three aspects were developed by Altemeyer (1996) based on nine characteristics of the authoritarian personality, namely: support for conventional rules, authoritarian submission, authoritarian aggression, stereotypes and rigidity, power, cynicism, projectivity, unconscious emotional impulses, and sexual barriers (Saunders \& Ngo, 2017).

Intergroup anxiety is felt by individuals when anticipating or interacting with individuals from different groups (Stephan, 2014). Through the person $X$ situation approach, intergroup anxiety is an interaction between the individual (person) and the environment (situation) (Britt et al, 1996). Four antecedents contribute to increasing or reducing the level of intergroup anxiety, namely: 1) personality and individual characteristics; 2) attitudes and perceptions; 3) personal experience; and 4) situational factors (Stephan, 2014; Stephan \& Stephan, 1985). These antecedents have a reciprocal relationship with intergroup anxiety, such as negative attitudes toward other groups or outgroups, causing intergroup anxiety. Likewise, the intergroup anxiety that arises when individuals interact with other groups will form negative attitudes towards group members. Intergroup anxiety has three aspects, namely: 1) the affective aspect, namely feelings of discomfort, anxiety, and pressure, which become a negative experience that leads to hostility; 2) cognitive aspects, in which individuals may judge that interactions between groups will lead to negative consequences; and 3) physiological aspects, resulting in individuals who feel intergroup anxiety to experience an increase in galvanic skin response (changes in the sweat glands in the skin), increased blood pressure, and an increase in cortisol levels (Stephan, 2014).

Prejudice will increase when society has many differences, such as ethnicity, religion, language, and political ideology, meaning social categorization becomes very prominent (Cohrs et al., 2012; Crawford et al., 2016). These prejudices can be caused by relationships that involve contact and interaction between groups, including emotions. When a social group has a warm and friendly impression of another group, positive emotions are created. Conversely, when a social group has a cold or unfriendly impression, this will create negative emotions (Irene \& Ampuni, 2020; Kotzur et al., 2019; Seger et al., 2017). Stephan and Stephan (1985) introduced intergroup anxiety as an experience that causes uncomfortable feelings when interacting with outgroups.

Based on the above description, it can be concluded that RWA and intergroup anxiety are two of the many factors that according to theory can influence prejudice against veiled Muslim women. There have been various previous studies examining the relationship between RWA and prejudice. Through the meta-analysis by Sibley and Duckitt (2008) 71 previous studies, it was established that personality, including RWA, was correlated with prejudice. In addition, several studies have examined the relationship between intergroup anxiety and prejudice. The results show that intergroup anxiety was able to predict prejudice between groups (Banas et al., 2020; Choma et al., 2016; Visintin et al., 2017). However, we are not aware of any previous studies which 
have examined the roles of RWA and intergroup anxiety together on prejudice in the context of veiled Muslim women. Therefore, this study aims to examine the role of right-wing authoritarianism and intergroup anxiety in such prejudice.

\section{Method}

Design

A quantitative method was employed, with a cross sectional survey design using a questionnaire to collect the data.

\section{Participants and Procedure}

The study participants $(\mathrm{N}=403)$ came from various ethnic and religious backgrounds and lived in the city of Surabaya. They were selected from an infinite population with an accidental sampling technique. The participants were involved voluntarily and anonymously, completing a questionnaire distributed online via social media (WhatsApp, Instagram, Twitter, and Line). They were male and female, or did not state their gender. Their age range was 18-30, selected with the consideration that at such an age individuals have a clear identity and can distinguish groups according to the categories that belong to other group members (Abrams, 2010).

\section{Instruments}

In the study, three self-reported questionnaires were used to collect data related to the three research variables and the demographics, together with open-ended questions to enrich these data. The scale of prejudice against veiled Muslim women was based on the three aspects that form prejudice according to Cohrs et al. (2012), namely cognitive, affective, and conative aspects, which were adjusted to the target of prejudice, veiled Muslim women. Before being used, the measuring tool was first subjected to a content validity test process with a CVR (content validity ratio) by three panelists. The item was said to have good content validity if it met the requirements, namely a CVR Indeks of $\geq 0.5$. The measuring instrument consisted of 18 items and was declared reliable following an internal consistency test using Cronbach's alpha formula, with $\alpha=0.908$. The cognitive aspects that measured the beliefs and knowledge of individuals that underlie negative assessments of veiled Muslim women consisted of six items; for example, "I think veiled Muslim women are suspicious" [ $\alpha=$.787]. The affective aspect, which measured individual emotional reactions to veiled Muslim women, also consisted of six items, an example being "I feel afraid when I have to interact with veiled Muslim women" $[\alpha=.775]$. Finally, the conative aspect, which measured the response of individual behavior to veiled Muslim women, again consisted of six items; for example, "I will avoid it if I get close to a veiled Muslim woman" $[\alpha=.801]$. The responses to the prejudice scale against veiled Muslim women were measured on a Likert scale, with five choices ranging from 1 (strongly disagree) to 5 (strongly agree).

The Right-Wing Authoritarianism Scale. The Right-Wing Authoritarianism (RWA) scale compiled by Altemeyer (2007) was employed. The tool was modified to adjust to the context of individual responses to veiled Muslim women. The RWA was declared reliable after undergoing an internal consistency test with Cronbach's alpha of $\alpha=.883$. The measuring instrument consisted of 20 items composed of three aspects, namely authoritarian submission, authoritarian aggres- 
sion, and conventionalism. The authoritarian submission aspect consisted of six items; for example, "What Indonesia really needs is a strong and resilient leader who prohibits the wearing of the veil by Muslim women" $[\alpha=.576]$. The authoritarian aggression aspect also consisted of six items, with "The only way for Indonesia to be able to get through the crisis is to silence veiled Muslim women" [ $\alpha=.807]$ being an example. The conventionalism aspect consisted of eight items; for instance "One day Indonesia will be destroyed if we do not get rid of veiled Muslim women" (favorable item) $[\alpha=.755]$. The responses to the RWA scale were on a five-choice Likert scale, from 1 (strongly disagree) to 5 (strongly agree).

The Intergroup Anxiety Scale. The Intergroup Anxiety Scale compiled by Stephan \& Stephan (1985) was used. The Cronbach's alpha coefficient value of the scale was .896, making the measuring instrument reliable. The tool was modified to measure feelings of discomfort or anxiety as a form of individual response when interacting with veiled Muslim women. To this end, the participants were asked to imagine themselves to be the only people who had to interact with a group of veiled Muslim women (for example, chatting with them or doing work together). Furthermore, they were asked to provide the level of appropriateness of their responses when engaging in such interactions. This measuring instrument consisted of 14 items composed of three aspects, namely affective aspects, cognitive aspects, and physiological aspects. The affective aspect comprised five items, an example being "I feel accepted by veiled Muslim women" [ $\alpha=$.700]. The cognitive aspect consisted of six items; for example, "I am careful when interacting with veiled Muslim women" $[\alpha=.784]$. Finally, the physiological aspect included three favorite items; for instance, "I feel my heart beating when I interact with Muslim women in the veil" $(\alpha=$ .895). The responses to the Intergroup Anxiety Scale were on a five-choice Likert scale, from 1 (very unsuitable) to 5 (very suitable).

\section{Data Analysis}

Descriptive analysis was used to describe the characteristics of the participants and the research variables. Pearson Product Moment bivariate correlation was used to evaluate the relationship between the research aspects and the variables. Furthermore, the research hypothesis was tested with multiple linear regression to determine the combined roles of RWA and intergroup anxiety on prejudice against veiled Muslim women. In addition, partial correlation analysis ( $t$ test) was used to determine the role of each independent variable (RWA and intergroup anxiety), with prejudice against veiled Muslim women as the dependent variable. All the statistical analysis used JASP Jeffrey's Amazing Statistics Program), version 0.14 (JASP, 2020).

\section{Results}

In Table 1, it can be seen that the study participants were in the age range of $18-30(\mathrm{M}=$ 20.9; $\mathrm{SD}=1.9$ ); the majority were women (74.2\%); just over half (50.1\%) were Muslim, $53.7 \%$ were Javanese, and 58.4\% had no Muslim friends who were veiled.

Prior to the multiple regression analysis, intervariable correlation was performed using Pearson's Correlation (Table 2). As a result, all the variables had a significant positive correlation. Furthermore, the multiple regression analysis (Table 3) showed that together, RWA and intergroup anxiety significantly predicted prejudice against veiled Muslim women. Partial 
analysis (Table 4) showed that RWA ( $\beta=.344$, 95\% CL [0.403, 0.599], t (401) = 10.028; $\mathrm{p}<.01)$ and intergroup anxiety $(\beta=.580,95 \%$ CL $[0.698$,
0.882], $\mathrm{t}(401)=16.915 ; \mathrm{p}<.01$ ) played a positive role in predicting prejudice against veiled Muslim women.

\section{Table 1}

Participants' Demographic Data; Mean and SD; Different Tests on Prejudice Variables

\begin{tabular}{|c|c|c|c|c|c|c|c|}
\hline $\begin{array}{l}\text { Demographic } \\
\text { Variable }\end{array}$ & Category & $\mathrm{N}$ & $\%$ & Mean & SD & $\mathrm{F}$ & $\mathrm{p}$ \\
\hline \multirow[t]{3}{*}{ Age } & $18-22$ years & 358 & 88.8 & 2.304 & 0.672 & 0.251 & .778 \\
\hline & $23-26$ years & 34 & 8.5 & 2.263 & 0.517 & & \\
\hline & $27-30$ years & 11 & 2.7 & 2.176 & 0.508 & & \\
\hline \multirow[t]{3}{*}{ Sex } & Female & 299 & 74.2 & 2.265 & 0.664 & 3.021 & .050 \\
\hline & Male & 90 & 22.3 & 2.344 & 0.608 & & \\
\hline & Not indicated & 14 & 3.5 & 2.681 & 0.678 & & \\
\hline \multirow[t]{6}{*}{ Religion } & Islam & 202 & 50.1 & 2.195 & 0.643 & 2.466 & .032 \\
\hline & Christian & 123 & 30.5 & 2.414 & 0.645 & & \\
\hline & Catholic & 49 & 12.2 & 2.394 & 0.592 & & \\
\hline & Hindu & 19 & 4.7 & 2.437 & 0.873 & & \\
\hline & Buddist & 7 & 1.7 & 2.034 & 0.702 & & \\
\hline & Konghuchu & 3 & 0.8 & 2.510 & 0.500 & & \\
\hline \multirow[t]{3}{*}{ Ethicity } & Javanese & 208 & 53.7 & 2.230 & 0.637 & 2.499 & .083 \\
\hline & Tionghoa & 94 & 23.4 & 2.404 & 0.692 & & \\
\hline & Other & 101 & 22.9 & 2.335 & 0.651 & & \\
\hline Having at least one & No & 236 & 58.4 & 2.383 & 0.681 & 9.967 & .002 \\
\hline veiled Muslim friend & Yes & 167 & 41.6 & 2.176 & 0.600 & & \\
\hline
\end{tabular}

Table 2

Descriptive Statistics and Bivariate Correlation Matrix

\begin{tabular}{lccc}
\hline & 1 & 2 & 3 \\
\hline RWA & - & & \\
Intergroup Anxiety & .569 & - & \\
Prejudice & .674 & .776 & - \\
Mean & 1.889 & 2.461 & 2.297 \\
SD & 0.638 & 0.630 & 0.656 \\
\hline
\end{tabular}

Table 3

Multiple Linear Regression Analysis of the Role of Both Prejudice Predictors

\begin{tabular}{cccccc}
\hline Predictor & $\mathrm{R}$ & $\mathrm{R}^{2}$ & Adjusted $\mathrm{R}^{2}$ & $\mathrm{~F}$ & $\mathrm{p}$ \\
\hline RWA, intergroup anxiety & .826 & .682 & .680 & 428.684 & $<.01$ \\
\hline
\end{tabular}

\section{Table 4}

Multiple Linear Regression Analysis the Role of each Predictor of Prejudice

\begin{tabular}{|c|c|c|c|c|c|c|c|c|}
\hline \multirow{2}{*}{ Predictor } & \multirow{2}{*}{ Unstandardized } & \multirow{2}{*}{ Standardized } & \multirow{2}{*}{$\begin{array}{l}\text { Effective } \\
\text { Contribution }\end{array}$} & \multirow{2}{*}{$\begin{array}{l}\text { Relative } \\
\text { Contribution }\end{array}$} & \multirow[b]{2}{*}{$\mathrm{t}$} & \multirow[b]{2}{*}{$\mathrm{p}$} & \multicolumn{2}{|c|}{$95 \% \mathrm{CI}$} \\
\hline & & & & & & & Lower & Upper \\
\hline RWA & .501 & .344 & .232 & .340 & 10.028 & $<.01$ & 0.403 & 0.599 \\
\hline $\begin{array}{l}\text { Intergroup } \\
\text { Anxiety }\end{array}$ & .790 & .580 & .450 & .660 & 16.915 & $<.01$ & 0.698 & 0.882 \\
\hline
\end{tabular}




\section{Discussion}

The results of the study (Table 3) indicate that together RWA and intergroup anxiety play a significant role in predicting prejudice against veiled Muslim women. Furthermore, from the results of the coefficient of determination, or adjusted $\mathrm{R}^{2}$ of 0.680 , it is demonstrated that they explain the emergence of prejudice against veiled Muslim women by 68\%. In other words, there are other factors beyond these two variables that can explain the remaining $32 \%$ of prejudice against Muslim women who wear the veil

Furthermore, the multiple regression results (Table 4) indicate that RWA has a positive role in explaining prejudice against veiled Muslim women. The positive standardized beta value shows that the higher the RWA, the greater the prejudice. These results are in line with previous research which showed that RWA was positively correlated with prejudice (Imhoff \& Bruder, 2014; Onraet et al., 2017).

The findings of this study support the theory that individual factors are able to predict prejudice (Cohrs et al., 2012; Kite \& Whitley, 2016). As a social ideology, RWA is a strong factor in forming prejudice against groups that are considered to threaten customary values, social norms, and moral values (Crawford et al., 2016). Individuals who have high RWA tend to have a rigid mindset, are inflexible, do not like novelty, and do not want to consider different moral rules and values (Cohrs et al., 2012). Such individuals will categorize the veiled Muslim women group as an outgroup that deviates from conventional rules, namely an order of social life that is free from terrorism and the values of radicalism. This predisposition results in the emergence of a tendency to be more aggressive toward veiled Muslim women.
The description above is in line with the findings of this study (Table 2), that the authoritarian aggression aspect has the greatest correlation with prejudice. It explains the tendency of individuals to be aggressive towards groups that are considered to break the rules (Gordon, 2017). When individuals believe that veiled Muslim women are a social threat, are disobedient and violate conventional rules, this will increase prejudice against them.

Furthermore, from Table 4 it can be seen that intergroup anxiety plays a positive role in predicting prejudice against veiled Muslim women. This means that when individuals perceive veiled Muslim women as an outgoup, the higher their prejudice against these women. This result is in line with the research of Choma et al. (2018), who found that there was a positive correlation between intergroup anxiety and prejudice.

This explains that individuals feel anxiety before interacting with groups or people who have different cultures (Stephan \& Stephan, 1985). This also applies to different racial and ethnic groups, as well as groups that have been stigmatized, such as veiled Muslim women.

Furthermore, individuals will feel anxious and uncomfortable when a certain group has a history of conflict, as well as veiled Muslim women, who are often associated with radical Muslims. This is supported by the results of this study, which show that compared to other aspects of intergroup anxiety, the affective aspect has the greatest correlation value with prejudice against veiled Muslim women. This aspect relates to unpleasant experiences felt by individuals and can lead to the emergence of prejudice (Stephan, 2014). When individuals feel anxiety and feelings of discomfort, individual prejudice against veiled Muslim women will also increase. 
Based on the multiple regression results (Table 4), from the standardized beta value it can be seen that intergroup anxiety plays a greater role than RWA in forming prejudice against veiled Muslim women. Stated in terms of the effective contribution, intergroup anxiety contributed $45 \%$, while RWA contributed $23.2 \%$. In other words, this research shows that intergroup anxiety plays a bigger role than RWA as a social ideology in forming prejudice against veiled Muslim women.

In this study, the role of intergroup anxiety was greater than RWA in predicting prejudice against veiled Muslim women (Table 4). This was because stereotypes against veiled Muslim women, such as their being symbols of controversy, fundamentalism, and terrorist behavior (Garcia Yeste et al., 2020, 2020; Karunia \& Syafiq, 2019; Rahman \& Syafiq, 2017; Rasyid \& Bukido, 2018; Soltani, 2016), stimulate more the emergence of anxiety and feelings of threat compared to the aggressive response generated by RWA. In the relationship between groups, terrorism that is perceived as a threat to life will create stereotypes, prejudice, and even discrimination. The threat posed by acts of terrorism carried out by radical groups can be explained by terror management theory. The results of research by Greenberg and Kosloff (2008) show that strong awareness of death or mortality will raise or reinforce stereotypes and negative attitudes towards other groups who are seen as the source of such threats.

After the acts of terror that occurred in the United States on 9/11, the media began to report that Muslims were a radical group, resulting in many Western leaders at that time feeling threatened by Islamic symbols, including the veils worn by some Muslim women (Satiti, 2017). During the New Order government in Indonesia, the wearing of the niqab was prohibited, especially in school environments (Wahidah \& Nuranisah, 2020). A series of bomb incidents in Indonesia was conducted by terrorist groups. In the bombing of three churches in Surabaya on 11 May 2018 the perpetrators involved veiled Muslim women. The pattern of religious-based terrorism in Indonesia shows that the involvement of women has been increasing (Asiyah et al,, 2020; Mulia, 2019). The way the media reports on these women further reinforces the stereotypes and negative attitudes of society towards them (Basante, 2019; Satiti, 2017). The interpretation of a situation and the emotions that arise in response to it can be predictors of prejudice against a group (Shepherd et al., 2018). This prejudice means veiled Muslim women often face discrimination, have no freedom, and have to survive under the Islamophobia that is felt by society (Hancock \& Mobillion, 2019; Satiti, 2017). When individuals interpret an act of terrorism carried out by a group of radical Muslims, it generates anxiety and fear as a form of individual response to the situation. Therefore, it is not surprising that the findings of this study suggest that intergroup anxiety has a greater influence on prejudice against veiled Muslim women than RWA.

As shown in Table 1, there are two other factors that play a role in explaining negative attitudes or prejudice towards veiled Muslim women: the presence or absence of participants' female Muslim friends who are veiled. Those who did not have such friends had higher prejudice than those who did.

This result is in line with the intergroup contact theory, which proposes that positive contact 
intensity can reduce intergroup prejudice (Pettigrew \& Tropp, 2006). Several recent studies have shown that intergroup contact can reduce prejudice against minority groups such as immigrants (e.g., Barni et al., 2020; Kotzur et al., 2019), and Muslims associated with bomb terror (Abrams et al., 2017).

Another finding in this study is that there are differences in prejudice against Muslim women who wear the veil based on religion. From the data in Table 1, it can be seen that non-Muslim participants had a higher prejudice against such Muslim women than Muslim participants. Apart from more intensive and positive contact, there are two other reasons that can explain this finding. First, the bombing that took place in the city of Surabaya in May 2018 targeted three churches, and one of the perpetrators was a veiled Muslim woman. Therefore, it is not surprising that the prejudice of Christian participants is higher than that of Muslims. Second, in general, compared to participants of other religions, Muslim ones had more comprehensive knowledge about the use of the niqab in Islam. The results of research by Zagefka et al. (2017) show that intergroup contact and knowledge influence intergroup contact and prejudice between groups.

Through direct contact experience with veiled Muslim women, a more positive attitude will be built, because intergroup contact can change negative stereotypical perceptions (Kotzur et al., 2019; Kotzur \& Wagner, 2021). The stereotype of veiled Muslim women that underlies prejudice is a belief bias due to inaccurate overgeneralization (Brown, 2010; Jones et al., 2014; Nelson, 2016).

Previous research has shown that in addition to intergroup contact, RWA and intergroup anxiety, other factors that influence prejudice against other groups include ethnocentrism (Bukhori, 2017; Tondok et al., 2017); stereotypes (Groyecka et al., 2019); relative deprivation (Santoso \& Hakim, 2012); collective narcissism (Ardi \& Budiarti, 2020); social dominance orientation (Choma et al., 2018); and religiosity and fundamentalism (Yafie et al., 2020). Research by Sulistio et al. (2020) shows that group identity and religious fundamentalism mediate the relationship between intergroup contacts and the prejudices of "Jama'ah Tabligh" adherents to the Muslim "Nahdatul Ulama" community in Semarang.

Based on the findings of this research, a reduction in the prejudice against Muslim women who are veiled or other outgroups, could be achieved by reducing RWA and intergroup anxiety. The basic aspects that constitute RWA are authoritarian parenting styles and socialization, namely by modeling through parents and friends, the media, and the presence of situational factors (Kandler et al., 2016; Saunders \& Ngo, 2017). To reduce RWA, individuals could model tolerant behavior towards veiled Muslim women through friends or the media.

Furthermore, intergroup anxiety in individuals also needs to be reduced in order to lessen prejudice against veiled Muslim women. Lack of knowledge about outgroups, lack of contact with outgroups, and worries about the emergence of negative behavior affect the levels of intergroup anxiety (Britt et al., 1996; Stephan \& Stephan, 1985). Therefore, increasing knowledge about veiled Muslim women, such as their relevant norms and moral values, could reduce intergroup anxiety. Involvement in positive direct interactions could also have the same effect. From the veiled Muslim group who joined the Niqab Squad 
community, socialization through the media was an effort to reduce intergroup anxiety, which in turn reduced prejudice against veiled Muslim women (Idntimes, 2019).

\section{Conclusion}

Based on the results and discussion, it can be concluded that RWA and intergroup anxiety together play a role in predicting prejudice against veiled Muslim women. The stronger these are, the stronger negative attitudes towards such women. Intergroup anxiety plays a greater role in predicting prejudice than RWA because of the strengthening of stereotypes that stem from the perceived anxiety and threat of veiled Muslim women.

\section{Suggestion}

The research was conducted in Surabaya, so the results cannot be generalized to populations with different characteristics. For this reason, similar studies could be conducted with different populations, by selecting participants proportionally and by considering demographic characteristics such as gender and ethnicity by making contact with outgroups and religion as moderator variables.

In practice, to reduce prejudice against a minority group, it is beneficial to increase the knowledge of it of other groups by understanding the values of the outgroup through more open interactions. [

\section{References}

Abrams, D. (2010). Processes of prejudices: Theory, evidence and intervention. Equality and Human Rights Commission Research Report Series, 56. Equality and Human Rights Commission https://www.equalityhumanrights.com/sites/default/files/research-report-56-processes-ofprejudice-theory-evidence-and-intervention.pdf

Abrams, D., Van de Vyver, J., Houston, D. M., \& Vasiljevic, M. (2017). Does terror defeat contact? Intergroup contact and prejudice toward Muslims before and after the London bombings. Peace and Conflict: Journal of Peace Psychology, 23(3), 260-268. https://doi.org/10.1037/pac0000167

Allport, G. (1954). The nature of prejudice. Addison - Wesley.

Altemeyer, B. (1996). The authoritarian specter. Harvard University Press.

Altemeyer, B. (2007). The authoritarians. Bob Altemeyer. https://theauthoritarians.org/options-forgetting-the-book/

Ardi, R., \& Budiarti, D. (2020). The role of religious beliefs and collective narcissism in interreligious contact on university students. Heliyon, 6(9), e04939. https://doi.org/10.1016/j.heliyon.2020.e04939

Asiyah, U., Prasetyo, R. A., \& Sudjak, S. (2020). Jihad perempuan dan terorisme. Jurnal Sosiologi Agama, 14(1), 125-140. https://doi.org/10.14421/jsa.2020.141-08

Banas, J. A., Bessarabova, E., \& Massey, Z. B. (2020). Meta-analysis on mediated contact and prejudice. Human Communication Research, 46(2-3), 120-160. https://doi.org/10.1093/hcr/hqaa004

Barni, D., Cavazza, N., Russo, S., Vieno, A., \& Roccato, M. (2020). Intergroup contact and prejudice toward immigrants: A multinational, multilevel test of the moderating role of individual conservative 
Prejudice against veiled Muslim women ....

values and cultural embeddedness. International Journal of Intercultural Relations, 75, 106-117. https://doi.org/10.1016/j.ijintrel.2020.02.004

Basante, P. N. (2019). Beyond the Veil: Media prejudice towards the use of the hijab in Europe. 5(1-2), 1322. https://doi.org/10.26021/781

BBC News. (2018a, May 13). Serangan bom di tiga gereja Surabaya: Pelaku bom bunuh diri "perempuan yang membawa dua anak." https://www.bbc.com/indonesia/indonesia-44097913\#orbbanner

BBC News. (2018b, August 3). Kisah perempuan bercadar: Diteriaki maling, dilempar botol, hingga ditawari pekerjaan. www.bbc.com/indonesia/indonesia-43302724

Berty, T. T. S. (2018). 10 fakta di balik tragedi 9/11 yang terjadi 17 tahun silam. https://www.liputan6. com/global/read/3640694/10-fakta-di-balik-tragedi-911-yang-terjadi-17-tahun-silam

BPS. (2013). Penduduk Indonesia hasil SP2010. Badan Pusat Statistik.

Britt, T. W., Bonieci, K. A., Vescio, T. K., Biernat, M., \& Brown, L. M. (1996). Intergroup anxiety: A person × situation approach. Personality and Social Psychology Bulletin, 22(11), 1177-1188. https://doi.org/10.1177/01461672962211008

Brown, R. (2010). Prejudice: Its social psychology (Second edition). Wiley-Blackwell.

Bukhori, B. (2017). Educational environment, ethnocentrism, and prejudice towards Indonesian Chinese. Anima: Indonesian Psychological Journal, 32(2), 109-115. https://doi.org/10.24123/aipj.v32i2.589

Choma, B. L., Haji, R., Hodson, G., \& Hoffarth, M. (2016). Avoiding cultural contamination: Intergroup disgust sensitivity and religious identification as predictors of interfaith threat, faith-based policies, and islamophobia. Personality and Individual Differences, 95, 50-55. https://doi.org/10.1016/j.paid.2016.02.013

Choma, B. L., Jagayat, A., Hodson, G., \& Turner, R. (2018). Prejudice in the wake of terrorism: The role of temporal distance, ideology, and intergroup emotions. Personality and Individual Differences, 123, 65-75. https://doi.org/10.1016/j.paid.2017.11.002

Cohrs, J. C., Kämpfe-Hargrave, N., \& Riemann, R. (2012). Individual differences in ideological attitudes and prejudice: Evidence from peer-report data. Journal of Personality and Social Psychology, 103(2), 343-361. https://doi.org/10.1037/a0028706

Crawford, J. T., Brandt, M. J., Inbar, Y., \& Mallinas, S. R. (2016). Right-wing authoritarianism predicts prejudice equally toward "gay men and lesbians" and "homosexuals". Journal of Personality and Social Psychology, 111(2), e31-e45. https://doi.org/10.1037/pspp0000070

Garcia Yeste, C., El Miri Zeguari, O., Álvarez, P., \& Morlà Folch, T. (2020). Muslim women wearing the niqab in Spain: Dialogues around discrimination, identity and freedom. International Journal of Intercultural Relations, 75(July 2019), 95-105. https://doi.org/10.1016/j.ijintrel.2020.02.003

Gordon, P. E. (2017). The authoritarian personality revisited: Reading Adorno in the age of Trump. Boundary 2, 44(2), 31-56. https://doi.org/10.1215/01903659-3826618

Greenberg, J., \& Kosloff, S. (2008). Terror management theory: Implications for understanding prejudice, stereotyping, intergroup conflict, and political attitudes. Social and Personality Psychology Compass, 2(5), 1881-1894. https://doi.org/10.1111/j.1751-9004.2008.00144.x

Groyecka, A., Witkowska, M., Wróbel, M., Klamut, O., \& Skrodzka, M. (2019). Challenge your stereotypes! Human Library and its impact on prejudice in Poland. Journal of Community \& Applied Social Psychology, 29(4), 311-322. https://doi.org/10.1002/casp.2402 
Halim, D. (2019, December 25). Kaleidoskop 2019: Sejumlah teror yang guncang Indonesia, bom bunuh diri hingga penusukan Wiranto. Kompas Online. https://nasional.kompas.com/read/2019/ 12/25/07485601/kaleidoskop-2019-sejumlah-teror-yang-guncang-indonesia-bom-bunuhdiri-hingga?page=all

Hancock, C., \& Mobillion, V. (2019). "I want to tell them, I'm just wearing a veil, not carrying a gun!" Muslim women negotiating borders in femonationalist Paris. Political Geography, 69(June), 1-9. https://doi.org/10.1016/j.polgeo.2018.11.007

Idntimes. (2019, November 16). Mengenal niqab squad, komunitas cadar Indonesia beranggota 44,3 ribu. https://www.idntimes.com/news/indonesia/lia-hutasoit-1/mengenal-niqab-squadkomunitas-cadar-indonesia-beranggota-443-ribu/4

Imhoff, R., \& Bruder, M. (2014). Speaking (un-)truth to power: Conspiracy mentality as a generalised political attitude. European Journal of Personality, 28(1), 25-43. https://doi.org/10.1002/ per.1930

Irene, G., \& Ampuni, S. (2020). Do intergroup threats provoke intergroup anxiety? An experimental study on Chinese ethnic group in Indonesia. Jurnal Psikologi Sosial, 18(3), 247-260. https://doi.org/10.7454/jps.2020.24

JASP. (2020).JASP: A fresh way to do statistics. https://jasp-stats.org

Jones, J. M., Dovidio, J. F., \& Vietze, D. L. (2014). The psychology of diversity: Beyond prejudice and racism. Wiley-Blackwell.

Kandler, C., Bell, E., \& Riemann, R. (2016). The structure and sources of right-wing authoritarianism and social dominance orientation. European Journal of Personality, 30(4), 406-420. https://doi.org/10.1002/per.2061

Karunia, F., \& Syafiq, M. (2019). Pengalaman perempuan bercadar. Character: Jurnal Penelitian Psikologi, 6(2), 1-13.

Kite, M. E., \& Whitley, B. E. (2016). Psychology of prejudice and discrimination. Routledge.

Kotzur, P. F., Schäfer, S. J., \& Wagner, U. (2019). Meeting a nice asylum seeker: Intergroup contact changes stereotype content perceptions and associated emotional prejudices, and encourages solidarity-based collective action intentions. British Journal of Social Psychology, 58(3), 668690. https://doi.org/10.1111/bjso.12304

Kotzur, P. F., \& Wagner, U. (2021). The dynamic relationship between contact opportunities, positive and negative intergroup contact, and prejudice: A longitudinal investigation. Journal of Personality and Social Psychology, 120(2), 418-442. https://doi.org/10.1037/pspi0000258

McFarland, S. (2010). Authoritarianism, social dominance, and other roots of generalized prejudice: Psychological roots of generalized prejudice. Political Psychology, 31(3), 453-477. https://doi.org/10.1111/j.1467-9221.2010.00765.x

Mulia, M. (2019). Bahaya radikalisme dan kekerasan ekstrismisme. Al-Wardah: Jurnal Kajian Perempuan, Gender dan Agama, 12(2), 96-106. https://doi.org/10.46339/al-wardah.v12i2. 137

Myers, D. G., \& Twenge, J. M. (2016). Social psychology (12 edition). McGraw-Hill.

Nelson, T. D. (Ed.). (2016). Handbook of prejudice, stereotyping, and discrimination (Second edition). Psychology Press, Taylor \& Francis Group.

Onraet, E., Van Hiel, A., De Keersmaecker, J., \& Fontaine, J. R. J. (2017). The relationship of trait emotional intelligence with right-wing attitudes and subtle racial prejudice. Personality and Individual Differences, 110, 27-30. https://doi.org/10.1016/j.paid.2017.01.017 
Pettigrew, T. F., \& Tropp, L. R. (2006). A meta-analytic test of intergroup contact theory. Journal of Personality and Social Psychology, 90(5), 751-783. https://doi.org/10.1037/0022-3514. 90.5.751

Rahman, A. F., \& Syafiq, M. (2017). Motivasi, stigma dan coping stigma pada perempuan bercadar. Jurnal Psikologi Teori dan Terapan, 7(2), 103-115. https://doi.org/10.26740/jptt.v7n2.p103-115

Rasyid, L. A., \& Bukido, R. (2018). Probematika hukum cadar dalam Islam: Sebuah tinjauan normatifhistoris. Jurnal Ilmiah Al-Syir'ah, 16(1), 74-92. https://doi.org/10.30984/jis.v16i1.648

Santoso, F., \& Hakim, M. A. (2012). Deprivasi relatif dan prasangka antar kelompok. Jurnal Psikologi, 39(1), 121-128. https://doi.org/10.22146/jpsi.6971.

Satiti, N. L. U. (2017). Representation of Muslim women in the western media. Jurnal Ilmu Komunikasi, 14(2), 189-202. https://doi.org/10.24002/jik.v14i2.789.

Saunders, B. A., \& Ngo, J. (2017). The right-wing authoritarianism scale. In V. Zeigler-Hill \& T. K. Shackelford (Eds.), Encyclopedia of Personality and Individual Differences (pp. 1-4). Springer International Publishing. https://doi.org/10.1007/978-3-319-28099-8_1262-1

Seger, C. R., Banerji, I., Park, S. H., Smith, E. R., \& Mackie, D. M. (2017). Specific emotions as mediators of the effect of intergroup contact on prejudice: Findings across multiple participant and target groups. Cognition and Emotion, 31(5), 923-936. https://doi.org/10.1080/02699931. 2016.1182893

Shepherd, L., Fasoli, F., Pereira, A., \& Branscombe, N. R. (2018). The role of threat, emotions, and prejudice in promoting collective action against immigrant groups: Emotions, prejudice and collective action. European Journal of Social Psychology, 48(4), 447-459. https://doi.org/10.1002/ejsp.2346

Sibley, C. G., \& Duckitt, J. (2008). Personality and prejudice: A meta-analysis and theoretical review. Personality and Social Psychology Review, 12(3), 248-279. https://doi.org/10.1177/1088868308319226

Soltani, A. (2016, April 8). Confronting prejudice against muslim women in the west. https://unu.edu/publications/articles/confronting-prejudice-against-muslim-women-in-thewest.html

Stephan, W. G. (2014). Intergroup anxiety: Theory, research, and practice. Personality and Social Psychology Review, 18(3), 239-255. https://doi.org/10.1177/1088868314530518

Stephan, W. G., \& Stephan, C. W. (1985). Intergroup Anxiety. Journal of Social Issues, 41(3), 157-175. https://doi.org/10.1111/j.1540-4560.1985.tb01134.x

Sulistio, S., Suryanto, S., Hadziq, A., \& Bulut, S. (2020). The mediating effect of group identity and religious fundamentalism on the association of intergroup contact with prejudice. Psikohumaniora: Jurnal Penelitian Psikologi, 5(2), 169-184. https://doi.org/10.21580/pjpp.v5i2.6486

Tondok, M. S., Indramawan, D. K., \& Ayuni, A. (2017). Does prejudice mediate the effect of ethnocentrism on discrimination? An empirical study on interethnic relations. Anima: Indonesian Psychological Journal,33(1), 41-56. https://doi.org/10.24123/aipj.v33i1.1440

Utomo, P. A. (2018, April 23). Pelaku aksi teror Paris di 2015 divonis 20 tahun penjara. https://internasional.kompas.com/read/2018/04/23/16203501/pelaku-aksi-teror-paris-di2015-divonis-20-tahun-penjara

Visintin, E. P., Voci, A., Pagotto, L., \& Hewstone, M. (2017). Direct, extended, and mass-mediated contact with immigrants in Italy: Their associations with emotions, prejudice, and humanity 
perceptions: Different types of intergroup contact and prejudice. Journal of Applied Social Psychology, 47(4), 175-194. https://doi.org/10.1111/jasp.12423

Wahidah, N., \& Nuranisah, E. (2020). Diskriminasi perempuan bercadar dalam perspektif hegemoni. AlMada: Jurnal Agama, Sosial, dan Budaya, 3(1), 39-49. https://doi.org/10.31538/almada. v3i1.530

Yafie, M. F., Solicha, \& Syahid, A. (2020). Muslim prejudice: Study of the effects of religiosity, fundamentalism, religious quest, and social domination orientation. Proceedings of the 2nd International Conference on Islam, Science and Technology (ICONIST 2019), Mataram, West Nusa Tenggara, Indonesia. https://doi.org/10.2991/assehr.k.200220.017

Zagefka, H., González, R., Brown, R., Lay, S., Manzi, J., \& Didier, N. (2017). To know you is to love you: Effects of intergroup contact and knowledge on intergroup anxiety and prejudice among indigenous Chileans. International Journal of Psychology, 52(4), 308-315. https://doi.org/10.1002/ijop.12229 